\title{
İzmit Kent Merkezi Yaya Bölgesi Durum Analizi
}

\author{
Ezgi ŞAHIN ${ }^{1 *(D)}$, Elif Ebru ŞişMAN ${ }^{1}$ \\ ORCID 1: 0000-0002-4931-4946 \\ ORCID 2: 0000-0002-5114-7980 \\ ${ }^{1}$ Tekirdağ Namık Kemal Üniversitesi, Güzel Sanatlar Tasarım ve Mimarlık Fakültesi, Peyzaj Mimarlığı Bölümü, \\ 59030, Tekirdağ, Türkiye. \\ *e-mail: esisman@nku.edu.tr
}

Öz

Yaya ulaşımı, dünya üzerindeki ilk ulaşım tipidir. Hızlı kentleşme ve otomobil kullanımının artması ile birlikte kentlerimizde ulaşım neredeyse tamamen araçlara yönelik düzenlenmeye başlamış ve ulaşımda ana unsurun yaya olduğu unutulmuştur. Yaya ulaşımı kentlinin en temel haklarından biridir. Aynı zamanda bireyin yaşadığı kenti daha iyi algılaması ve orayı sahiplenmesi açısından önemli bir role sahiptir. Bu çalışmada, İmit kent merkezinde yoğun yaya kullanıma sahip olan yaya bölgesi örnek alan olarak seçilmiştir. Araştırma kapsamında seçilen alanın mevcut durumunu ortaya koymak için alanda sörvey çalışması yapılmış peyzaj tasarım ilkeleri doğrultusunda değerlendirmeler yapılmıştır. Alanda ayrıca mevcut durum değerlendirilmesine yönelik olarak kullanıcılarla ve işyeri sahipleri ile birebir memnuniyet anketleri yapılmıştır. Elde edilen verilere göre araştırma alanının sorunları belirlenmiş çeşitli öneriler geliştirilmiştir.

Anahtar Kelimeler: Yaya, yaya bölgesi, yayalaştırma, İzmit

\section{Current Situation Analysis of Pedestrian Area in Izmit City Center}

\begin{abstract}
Pedestrian transportation is the first type of transportation in the world. With the rapid urbanization and the increase in automobiles, transportation in our cities has started to be organized almost entirely for vehicles, and it has been forgotten that the main factor in transportation is pedestrian. Pedestrian transport is one of the most fundamental rights of people living in a city. Simultaneously, it has an essential role in perceiving and owning the city where the individual lives better. In this study, the pedestrian zone, which has intensive pedestrian use, was selected as the sample area in Izmit city center. In order to reveal the current situation of the selected area within the scope of the research, surveys were carried out in the area and evaluations were made under the landscape design principles. Besides, one-to-one satisfaction surveys were conducted with users and business owners to evaluate the area's current situation. According to the data obtained, various suggestions have been developed for the problems of the research field.
\end{abstract}

Keywords: Pedestrian, pedestrian areas, pedestrianization, Izmit

Atıf/Citation: Şahin, E, Şişman, E. E. (2021). İzmit Kent Merkezi Yaya Bölgesi Durum Analizi. Journal of Architectural Sciences and Applications, 6 (1), 237-249. DOI: 10.30785/mbud.900085 


\section{Giriş}

Insanların yaşam alanlarından biri olan kentlerde, insanların günlük hayatlarını en yüksek düzeyde faydayla sürdürebilmeleri için kentlerin planlanmasında önemli yere sahip olan ulaşım dokusunun, hem yayalar hem de araçlar için uygun olan en iyi şekilde düzenlenmesi gerekmektedir. Kentin belkemiği olan ulaşım dokusu aynı zamanda kentteki arazi kullanım kararları arasında bütünlük sağlayan bir yapı özelliği taşımaktadır. Bu yapının en önemli kullanıcıları kentteki insanlar yani kent ulaşımındaki yayalardır. Günümüzde hızlı kentleşme ve artan araç trafiği nedeniyle özellikle şehir merkezinde insanların rahatça dolaşması engellenmektedir (Şişman, 2013). Insanlara güvenli, rahat, kısmen veya tamamen araç trafiğinden arındırılmış açık alanlar sağlamak sosyal, estetik ve ekonomik açıdan önemlidir (Şişman ve Kırzıoğlu, 2002).

Yaya, kent içinde belirli uzaklıklara yürüyerek ulaşan kimsedir (Keleş, 1980). Tarihi yerleşmeler yaya dolaşımını dikkate alarak planlanmıştır (Kuntay, 1994). Atlar ve arabaların kullanılmaya başlanması ile yayalar yol kenarların itilmiş, özellikle otomobil kullanımın artması ile beraber yayalar yollardan yükseltilmiş kaldırımları kullanmak zorunda bırakılmıştır (Sen, 1999; Rosen, 2006). Kentlerdeki yoğun yapılaşma ve trafik beraberinde çevre sorunlarını getirmiş buna bağlı olarak planlamacılar bu sorunlara çözüm olarak kent merkezlerinde yaya bölgeleri oluşturma ile çözüm aramışlardır. Yaya bölgeleri; yayaların yürümelerine, çocukların bağımsız hareket ederek oynamalarına, daha fazla yeşil ve sosyal alan ile daha az trafik ve düşük düzeyde araç kullanımına olanak sağlarlar (Melia, Barton ve Parkhurst, 2010; Ornetzeder, Hertwich, Hubacek, Korytarova ve Haas, 2008). Aynı zamanda yaya bölgeleri kentsel, kamusal mekanları insanlar için yaşanabilir kılan alanlardır (Şişman ve Etli 2007). Yaya bölgeleri, insanların yaşam kalitesini yükselten yaya güvenli, konforlu ve estetik bir yaşam alanı sunar (Neill 2002). Birçok ülke tarafından kabul edilen Yaya Hakları Bildirgesi'ne göre; yaya kaldırımları yayalarındır, kent merkezi yaya bölgelerinindir, yaya geçitlerinde üstünlük yayalarındır, kent yaşamının gerçek sahipleri yayalardır (Çermikli, 2009).

Yaya bölgesi oluşturma amaçı̀ı yapılan yayalaştırma çalışmaları, tarihi binaların ve kent dokusunun korunması, perakende ticaretin arttırılması, konut alanlarının iyileştirilmesi, çevrenin güzelleştirilmesi, sosyal hayatın canlandırılması gibi sebeplerle planlı olarak yapılmaktadır (Çalışkan, 2011).

Almanya'nın Essen kentinde 1926 yılında gerçekleştirilen "Limbecker Strasse" yaya bölgesi ilk örneklerdedir (Rubenstein, 1992). Avrupa'da İkinci Dünya Savaşı sonrasında yıkılan, harap olan şehirlere yaya bölgesi uygulamaları ile çözüm aranmış ve Avrupa'nın pek çok kentinde uygulanmıştır. Amerika'da yaya bölgeleri uygulamalarına, Avrupa'daki uygulamalardan farklı olarak kent merkezinde gerileyen perakende ticaret fonksiyonlarının ekonomik açıdan şehir dışındaki alışveriş merkezleri karşısında rekabetini sağlamak amacıyla başlanmıştır. Avrupa'daki uygulamalardan ilham alan planlamacılar 1959'da Michigan Eyaletindeki Kalamazoo'da iki yapı bloğu boyunca yolu trafiğe kapatarak Amerika'da yayalaştırma faaliyetlerinin ilk adımını atılmışır (Carr, Francis, Rivlin ve Stone, 1992). Aru 1965'e göre ülkemizdeki ilk yayalaştırma örneği İstiklal Caddesidir. Bunu ülkemizde diğer büyükşehirlerdeki örmekler takip etmektedir.

Günümüzde, kentsel planlama, tasarım ve uygulama çalışmaları değerlendirildiğinde motorlu araç ulaşımının, yaya ulaşımından öncelikli ele alındığı görülmektedir. Kentlerimizde yayalara yönelik yönetmelik ve düzenlemeler yetersizdir.

Bu çalışmada amaç; İzmit kent merkezi örneğinde yaya bölgesi olarak düzenlenen mekanların durum analizini yapmak, ihtiyaçlara ne ölçüde cevap verdiğinin sorgulamak ve kullanıcılarının uygulama sonrasında memnuniyet durumlarını belirlemektir.

\section{Materyal ve Yöntem}

Izmit kent merkezinde, batıda Merkez Bankasından başlayarak, Yahya Kaptan'a oradan da, Kartepe Illçesi Köseköy tren istasyonu bitimine kadar uzanan, 10-12m genişliğinde, yaklaşık 17 km'lik bir alanda yürüyüş yolu bulunmaktadır. Kentin merkezinde yayalar için ayrılmış olan alan, çok çeşitli etkinlikleri içerisinde barındıran bir yaya bölgesi olarak düzenlenmiştir. Bu uzun yürüyüş yolu üç ana kısımda incelenebilir. Merkez Bankasından başlayarak Anıt Parka kadar uzanan birinci kısım, Anıt Parktan 
Kandıra sapağına kadar olan ikinci kısım ve Kandıra sapağından Köseköy tren istasyonunun bitimine kadar olan üçüncü kısım (Şekil 1).

Bu çalışmanın ana materyalini bu bölge içerisindeki Cumhuriyet Caddesi, Hürriyet Caddesi, Atatürk Bulvarı ve Cengiz Topel Caddelerinin (Eski Demiryolu Caddesi) birleşiminden oluşan yaklaşık 2 km'lik alan boyunca uzanan yaya bölgesi oluşturmaktadır (Şekil 2). Çalışma alanının belirlenmesinde; tarihi bir geçmişinin olması, kent merkezinde ve yoğun olarak kullanılması, çevresinde kentsel koruma alanlarının bulunması etkili olmuştur.

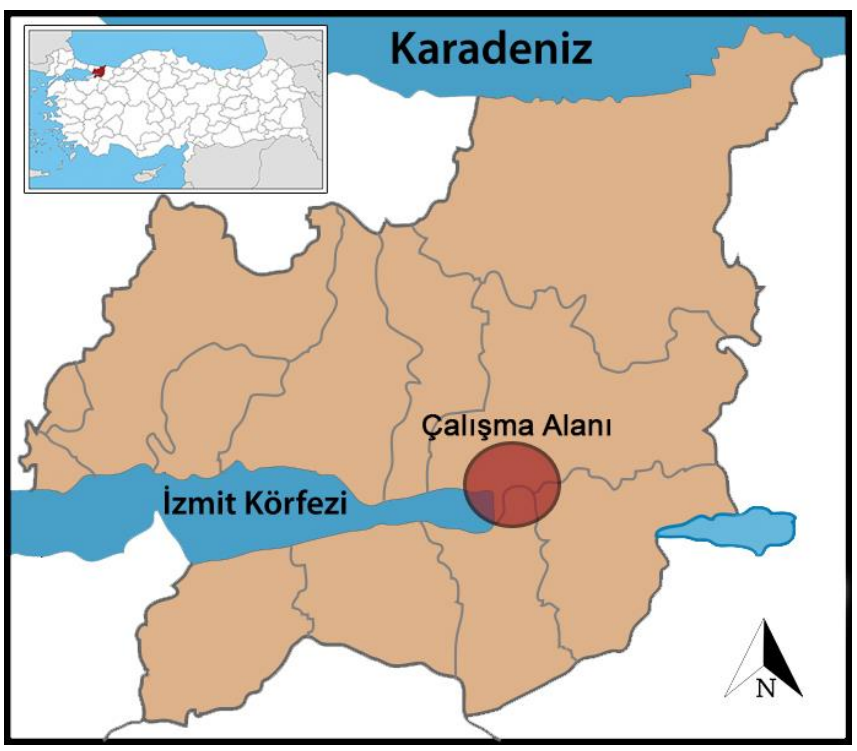

Şekil 1. Çalışma alanının konumu
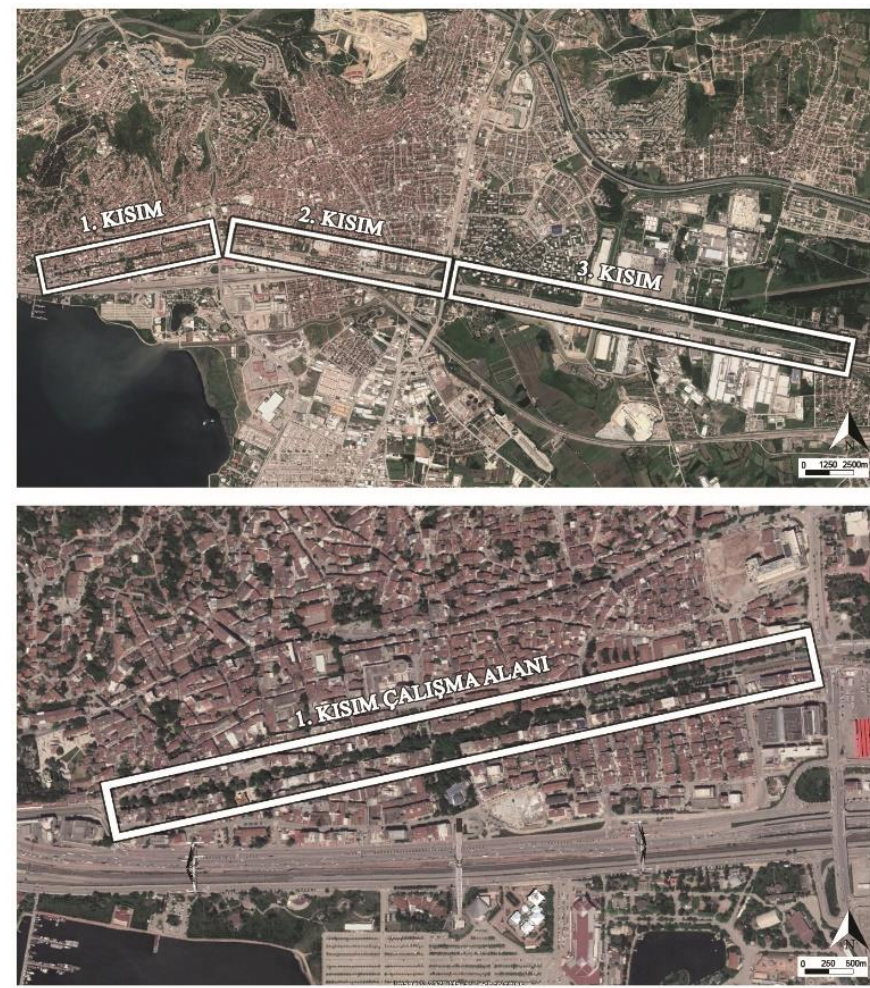

Şekil 2. Çalışma alanının sınırları

Uzun yıllar demiryolu olarak kullanılan alan (Şekil 3), 19 Ağustos 1999 Gölcük depreminden sonra demir yolunun şehir dışına çıkarılmasıyla ilk olarak faytonlara ayrılmış daha sonra ise yayalar için düzenlenmiştir. 

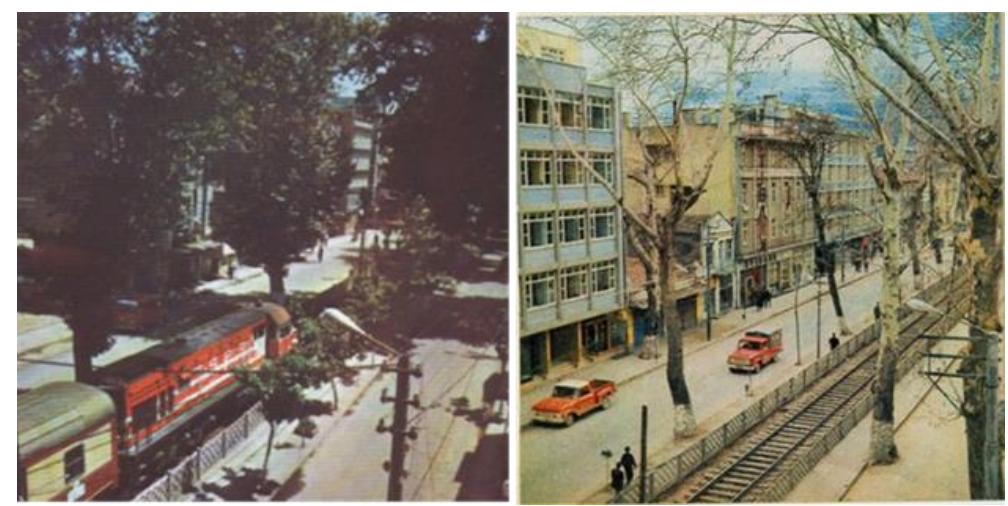

Şekil 3. 1930 'larda şehrin içinden geçen demir yolu hattı

Yürüyüş yolunun bazı noktalarında eskiyi hatırlatması için tren istasyonu işaret ve levhaları kullanılmış, alanın tarihi canlı tutulmaya çalışılmıştır (Şekil 4). Yayalaştırma çalışmasıyla canlanan alan çevresinde; 6-7 katlı konut alanlarının yanı sıra, i̇mit Saat Kulesi, çeşitli bankalar, kamu kurum ve kuruluşlar, parklar, öğrenci yurtları, apartlar, oteller ve alışveriş alanları bulunmaktadır.

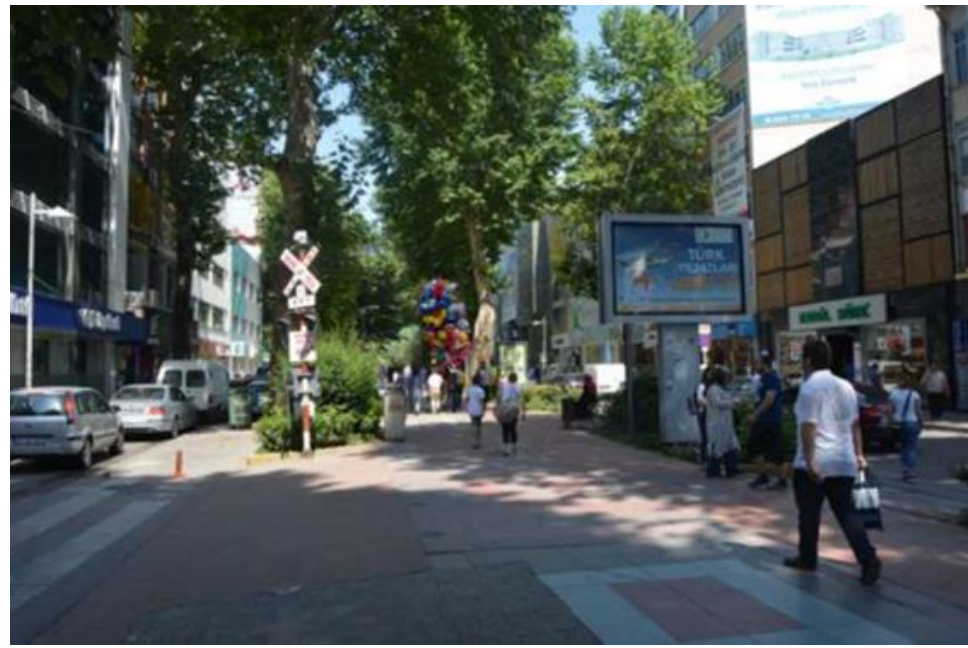

Şekil 4. Demiryolu hattı işaret levhaları

Çalışma yöntemi üç aşamada gerçekleştirilmiştir. İlk aşamada araştırma konusuna yönelik olarak literatür taraması yapılmış, alana ait 1/1000 ölçekli imar paftalarından, konuya ilişkin yasa ve yönetmeliklerden yararlanılmıştır.

ikinci aşamada, çalışma alanın mevcut durumunu belirlenmek üzere alanda veri toplama, gözlem ve belgeleme (fotoğraf çekimi ve ölçümler) çalışmaları yürütülmüştür. Elde edilen verilerle peyzaj düzenlemesine ilişkin peyzaj tasarım ilkeleri doğrultusunda değerlendirmeler yapılmıştır. Üçüncü aşamada ise yaya alanında kullanıcıların ve işyeri sahiplerinin alan hakkındaki görüşlerini belirlemek, alanın kullanıcıların ihtiyaçlarını ne ölçüde karşıladığını ortaya koyabilmek amacıyla, kullanıcı ve esnaf için ayrı ayrı hazırlanmış ve rastgele seçilen katılımcılarla yüz yüze görüşülerek anket çalışması yapılmıştır. Kullanıcı anketi örneklem büyüklüğünün saptanması için:

$$
n=N t^{2} p q / d^{2}(N-1)+t^{2} p q \text { formülü kullanılmıştır. }
$$

n: Örnekleme alınacak birey sayısı

p: İncelenen olayın görülüş sıklığı (gerçekleşme olasılığı)

q: İncelenen olayın görülmeyiş sıklığı (gerçekleşmeme olasıılı̆ı)

$\mathrm{t}$ : Belirli bir anlamlılık düzeyinde, $\mathrm{t}$ tablosuna göre bulunan teorik değer

d: Olayın görülüş sıklığına göre kabul edilen örnekleme hatasıdır.

Formülden yararlanılarak örneklem büyüklüğü 250 kişi olarak belirlenmiştir. Hürriyet ve Cumhuriyet Caddeleri boyunca uzanan yaya bölgesi kullanıcılarından rastgele seçilen 250 kişiye, 11 ve alanda bulunan işyeri sahiplerinden ankete katılmak isteyen 78 kişiye ise 12 soru yöneltilmiştir. Anket soruları kapalı uçlu sorulardan oluşturulmuş ve katılımcıların düşüncelerini en iyi yansıtan seçenekleri 
işaretlemeleri istenmiştir. Anketler iki veya daha fazla veri seti arasında karşılaştırma yapılmak istenildiğinde ve değişkenler arasında anlamlı bir ilişki olup olmadığını sorgulayan Khi-kare Testi (ChiSquare, $x^{2}$ ) ile değerlendirilmiştir. Araştırma için güven düzeyi (p) 0,05 olarak belirlenmiş ve ilişkinin anlamlılı̆̆ konusunda \%5'lik bir yanılma payı ile çalışıımıştır.

\section{Bulgular ve Tartışma}

\subsection{Yapısal Peyzaj Elemanlarının Değerlendirilmesi}

İzmit'in merkezinde bulunan çalışma alanına gerek yerel halk tarafından gerekse çevre bölgelerden kolayca ulaşılabilmektedir. Cumhuriyet Caddesi ortalama $12 \mathrm{~m}$ genişliğinde bir alan boyunca uzanmaktadır. Çalışma alanı caddenin ortasında olup caddeyi ikiye böler (Şekil 5). Alanda farklı döşeme kaplaması ile belirlenmiş bir de bisiklet yolu bulunmaktadır. Cadde de trafik tek yönlüdür. Çalışma alanının konumu gereği yapıların bir bölümü konut olarak kullanıııken, büyük bir bölümü de iş yeri olarak kullanılmaktadır. Bundan dolayı alanda yoğun yaya ve araç trafiği bulunmaktadır. Bu durum otopark ihtiyacını gündeme getirmiştir.

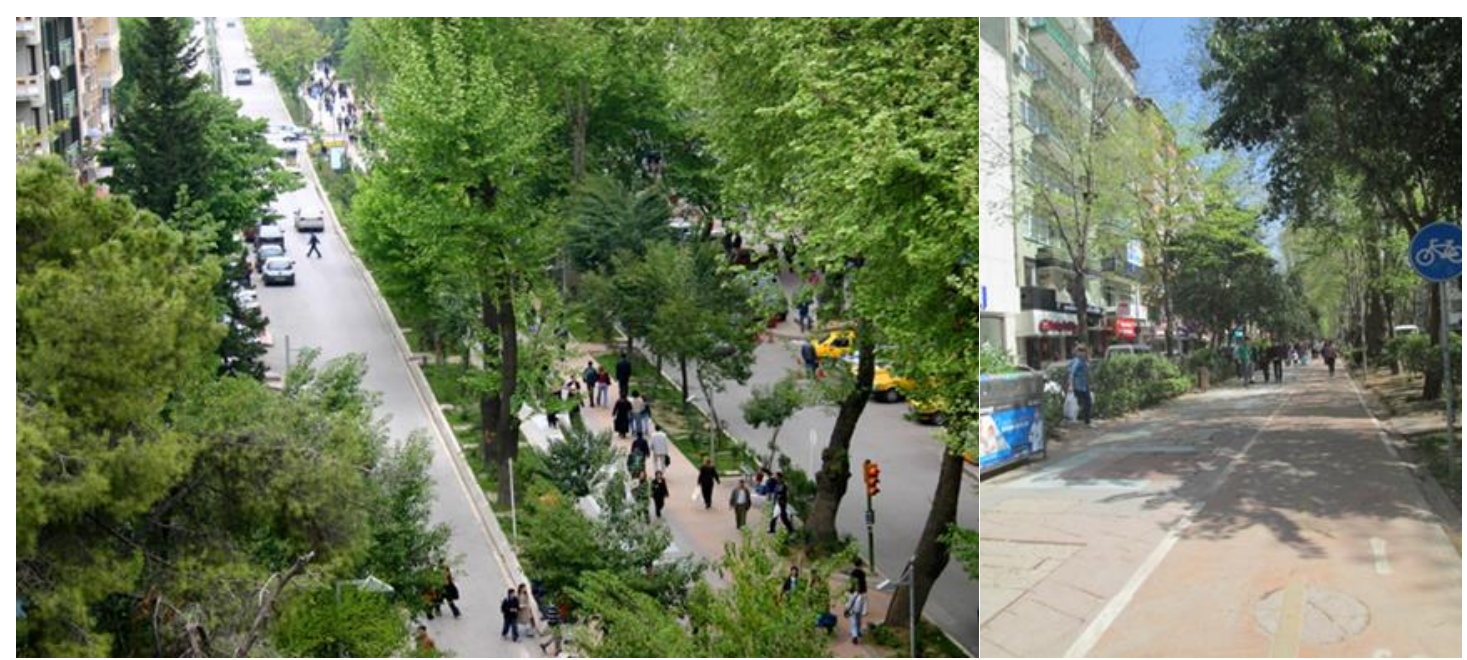

Şekil 5. Çalışma alanındaki araç, yaya ve bisiklet yolu

Yaya bölgesinde kullanılan donatı elemanları, sokak kütüphanesi, müzik durağı, satış birimleri, telefon kabinleri, çeşme, aydınlatma birimleri, çöp kutuları ve döşeme elemanlarıdır (Şekil 6).

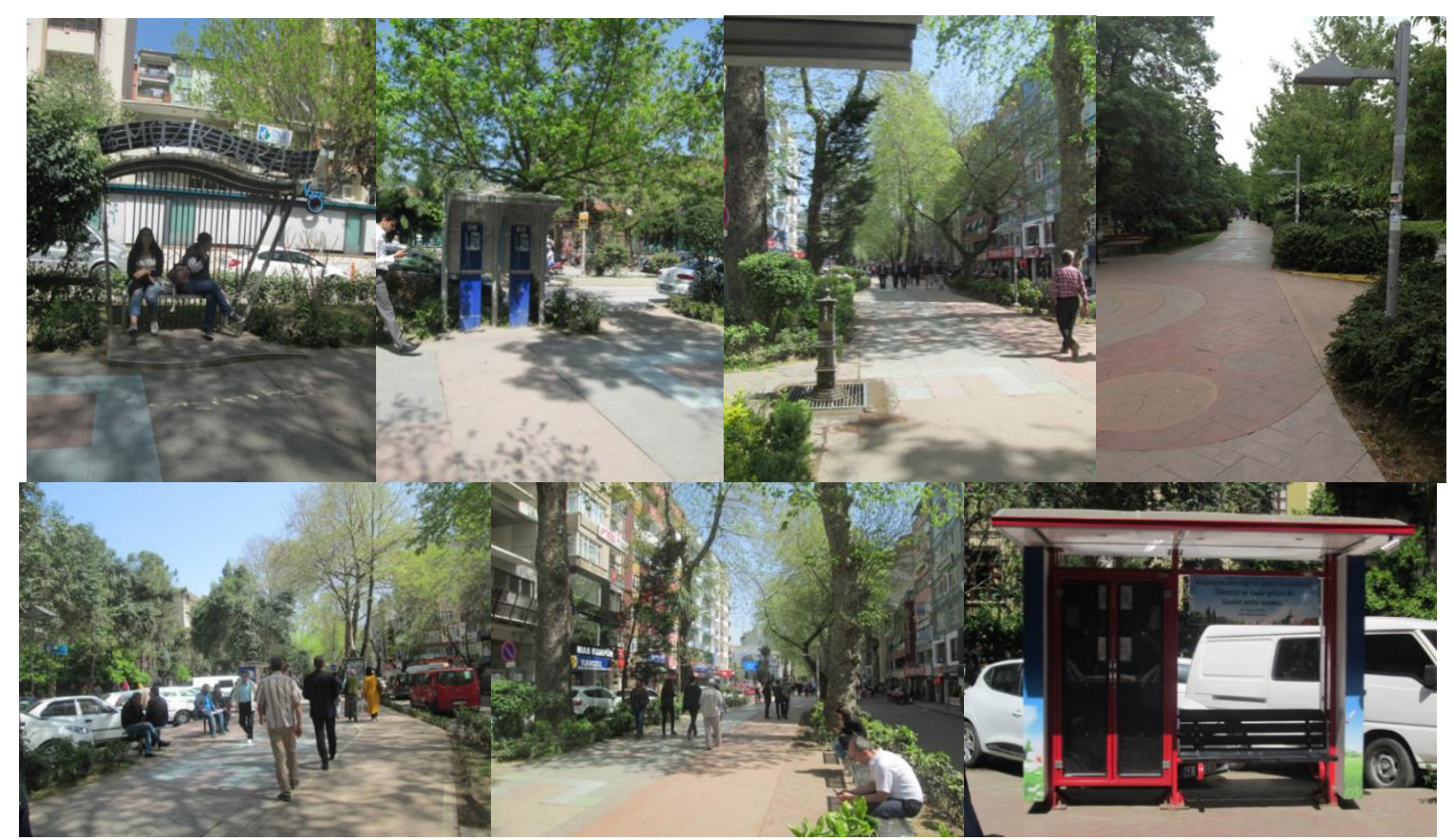

Şekil 6. Yaya bölgesinde kullanılan donatı elemanları 


\subsection{Bitkisel Peyzaj Elemanlarının Değerlendirilmesi}

Çalışma alanının mevcut yeşil alan durumu ele alındığında; araştırma alanında, yaprak döken ve herdemyeşil ağaçlar ve ağaç̧̧ılarla, yine yaprak döken ve herdemyeşil çalı gruplarına rastlanmaktadır. Alanda bitkisel anlamda en çok dikkat çeken, geniş tepe tacına ve yüksek boylanmaya sahip, yürüyüş yolu boyunca kullanılmış olan tarihi Platanus orientalis L. (Doğu çınarı) ağaçlarıdır (Şekil 7). Çalışma alanında belirlenen bitkisel materyal Çizelge 1 ' de verilmiştir.

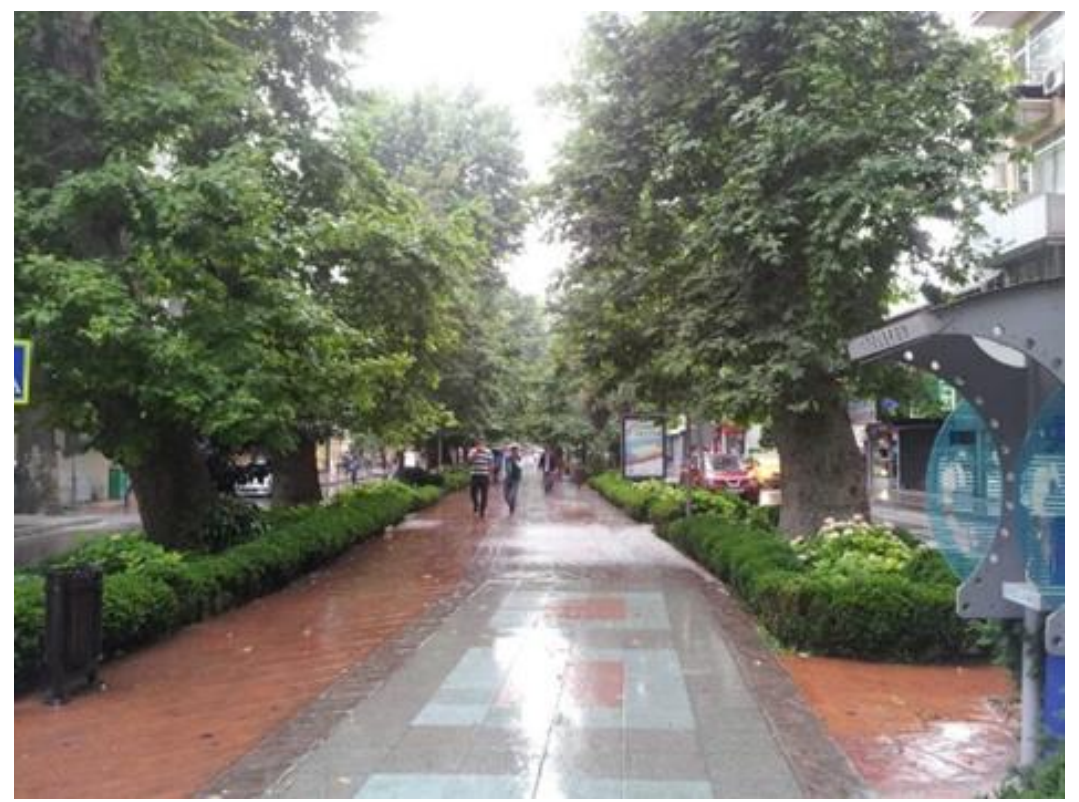

Şekil 7. Alanda bulunan Platanus orientalis L. (Doğu çınarı) ağaçlarının görünümü

Çizelge 1. Çalışma alanında belirlenen bitkiler

\begin{tabular}{ll}
\multicolumn{1}{c}{ Bitkinin Latince/Türkçe Adı } & \multicolumn{1}{c}{ Bitkinin Latince/Türkçe Adı } \\
\hline Acer campestre (Ova Akçaağacı) & Juniperus horizontalis (Sürünücü ardıç) \\
Acer negundo (Dişbudak yapraklı akçaağaç) & Lagerstroemia indica (Oya ağacı) \\
Acer platanoides (Çınar yapraklı akçaağaç) & Laurus nobilis (Akdeniz defnesi) \\
Aesculus hippocastanum (Beyaz çiçekli at & Ligustrum lucidum (Çin kurtbağrı) \\
kestanesi) & \\
Aucuba japonica (Japon akubası) & Liriodendron tulipfera (Lale ağacı) \\
Berberis thumbergii (Kadın tuzluğu) & Magnolia grandiflora (Büyük çiçekli manolya) \\
Buxus microphylla (Küçük yapraklı şimşir) & Nerium oleander (Adi zakkum) \\
Calocedrus decurrens (Kaliforniya su sediri) & Parthenocissus quinquefolia Amerikan sarmaşığı) \\
Cedrus atlantica( Atlas sediri) & Philadelphus coronarius (Yalancı yasemin) \\
Cedrus deodora (Himalaya sediri) & Photinia fraseri “Red Robin" (Alev Çalısı) \\
Cestrum purpureum (Narin melez yasemin) & Picea abies Avrupa ladini) \\
Cotoneaster franchetti (Tibet dağ muşmulası) & Pittosporum tobira \\
Cupressocyparis leylandii (Leylandi melez servisi) & Platanus orientalis (Doğu Çınarı) \\
Cupressus macrocarpa(Limoni servi) & Platanus x acerifolia (Akçaağaç yapralı çınar) \\
Cupressus sempervirens (Adi servi) & Platycladus orientalis(Doğu mazısı) \\
Elaeagnus angustifolia, (Kuş iğdesi) & Prunus cerasifera (Süs eriği) \\
Eriobotrya japonica (Malta eriği) & Punica granatum (Süs Narı) \\
Euonymus japonica "Aurea" (Altuni taflan) & Pyracantha coccinea (Ateş dikeni) \\
Hedera helix(Orman srmaşığı) & Robinia pseudoacacia (Beyaz çiçekli yalancı akasya) \\
Hibiscus syriacus (Ağaç hatmi) & Thuja occidentalis (Batı mazısı) \\
Hydrangea macrophylla (Ortanca) & Tilia tomentosa (Gümüşi ıhlamur) \\
llex aquifolium (Ingiliz çobanpüskülü) & Viburnum tinus (Defne yapraklı kartopu) \\
\hline
\end{tabular}

\subsection{Anket Sonuçlarının Değerlendirilmesi}

Çalışma alanında kullanıc memnuniyetini ölçmek amacıyla yayalar ile 250 adet, caddede faaliyet gösteren işyeri sahipleri ile ise 78 adet anket yapılmıştır. Anket soruları kapsamında kullanıcılarla 
yapılan görüşmelerde, katılımcılara sorulan sorular iki bölümden oluşmaktadır. Birinci bölümde; cinsiyeti, yaş grubu, eğitim durumu soruları sorulmuştur. İkinci bölümde ise yaya bölgesindeki alan kullanımlarına yönelik soruların cevaplandırılması istenmiştir.

\subsubsection{Yaya bölgesi kullanıcılarıyla yapılan anketlerin değerlendirilmesi}

Ankete katılanların \%46'sını kadın katılımcılar oluştururken \%54'ünü erkek bireyler oluşturmaktadır. Katılımcıların en küçüğü 16, en büyüğü 65 yaşında olup katııımıların \%44 gibi büyük bir oranını 19-24 yaş grubu oluşturmaktadır. Bunun yanında \%20'ini 18 yaş altı katılımcılar, \%20'sini 25-35 yaş grubu oluştururken, $\% 10^{\prime}$ unu $36-50$ yaş grubu ve $\% 6^{\prime}$ Iık kısmını da $51-65$ yaş grubu oluşturmaktadır. Ankete katılanların eğitim durumları incelendiğinde alanda bulunan okullarında etkisiyle üniversite ve lise eğitimi alan katılımcıların çoğunlukta olduğu görülmektedir. Katılımcıların \%8'ini ortaokul mezunları oluştururken, \%2'si okur-yazar olmayıp, \%4'lük kısmını da lisansüstü eğitimi almış ya da almakta olan bireyler oluşturmaktadır.

Ankette katılanların \%56 gibi büyük bir kısmını alan çevresinde bulunan okullara nedeniyle öğrenciler, $\% 18^{\prime}$ ini memurlar, $\% 8^{\prime}$ ini işsizler, \%4'ünü emekli ve \%2'lik kısmını da ev hanımları oluşturmaktadır.

Katılımcıların yaya bölgesini ne amaçla kullandıkları sorusu doğrultusunda kullanıcıların çoğunlukla alanı yürüyüş (\%22), dinlenme (\%20), alışveriş yapma (\%18) gibi etkinlikler için kullandıkları, en az da buluşma (\%2) ve fotoğraf çekmek (\%3) için kullanıldığı görülmüştür (Şekil 8).

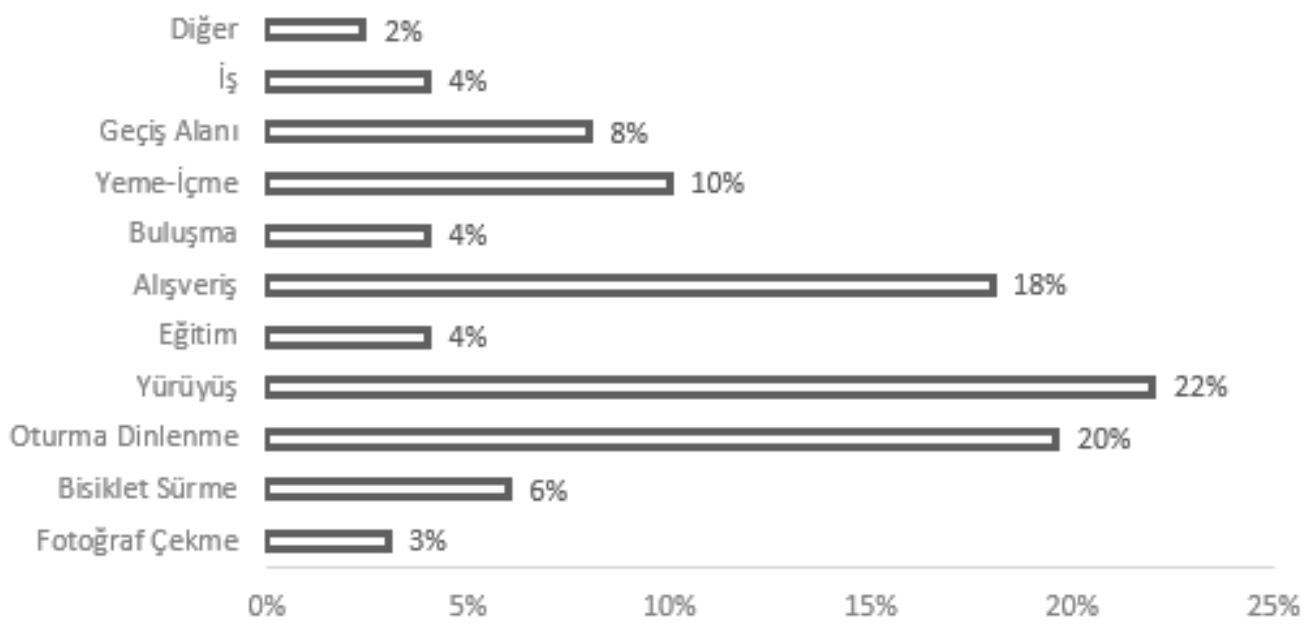

Şekil 8. Yayaların alanı kullanım amaçları

Kent merkezinde ikamet edenler caddeyi genellikle yaya (\%30) olarak ziyaret etmektedirler. Bunun dışında kalan kullanıcıları çevre yerleşim birimlerinden alana farklı amaçlar için toplu taşıma, servis, özel araçlar gibi yollarla gelmektedirler. Alana gelenlerin $\% 6^{\prime}$ ।ık kısmını bisiklet ve motosiklet kullanıcıları oluşturmaktadır (Şekil 9).

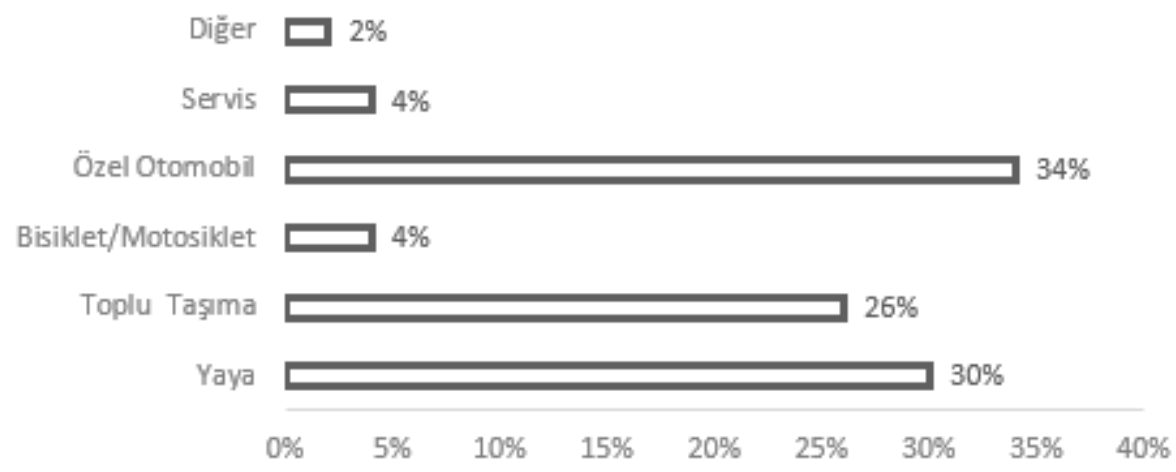

Şekil 9. Yayaların alana ulaşım şekli

Katılımcıların alana gelme sıklıklarına bakıldığında; \%52'si her gün, \%20'si günde birkaç kez, \%20'si haftada bir ve \% $8^{\prime} \mathrm{i}$ ise nadiren cevabını vermişlerdir (Şekil 10). 


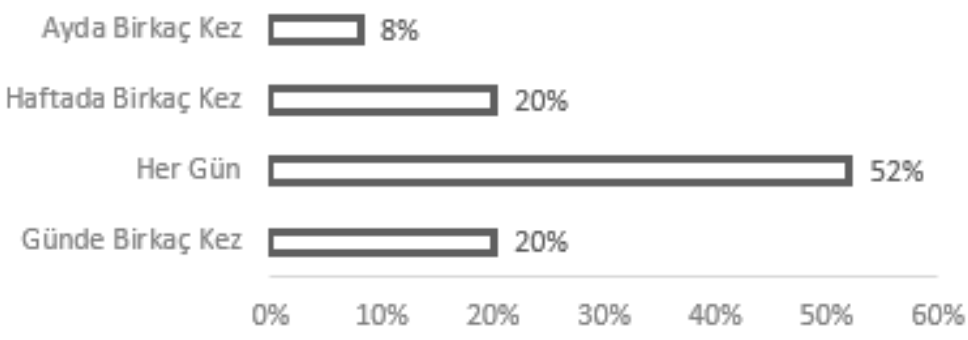

Şekil 10. Yayaların alanı kullanım sıklığı

Ankete katılanların, \%86 gibi büyük bir kısmı yaya bölgesinin çevreyi olumlu yönde etkilediğini, \%10’u çevreyi olumsuz etkilediğini, \%4'ü ise fikri olmadığını belirtmişlerdir.

Ankete katılan bireylere yaya bölgesinde işlevsel ya da estetik açıdan beğenmedikleri unsurlar sorulmuş ve yanıt olarak katılımcıların $\% 22$ 'i alanda otopark sıkıntısı olduğu yanıtını vermişlerdir. $\% 20^{\prime}$ lik kısmı alanın kalabalık ve gürültü olmasından şikayet ederken, \%14'ü oturma alanlarını yetersiz bulmaktadır. Katılımcıların \%12'si araç trafiğinden olumsuz etkilenmektedir. \%10'luk kısım çöp kutusu ve aydınlatma elemanı gibi alanda bulunması gerekli temel donatı elemanlarını yetersiz bulmaktayken katılımcıların \%8'i genel olarak yaya bölgesini bakımsız bulmuştur. \%2'lik kısım ağaçlara konan kuşların yerleri ve oturma alanlarını pislettiğini ve bu durumdan rahatsız olduklarını belirtmişlerdir (Şekil 11).

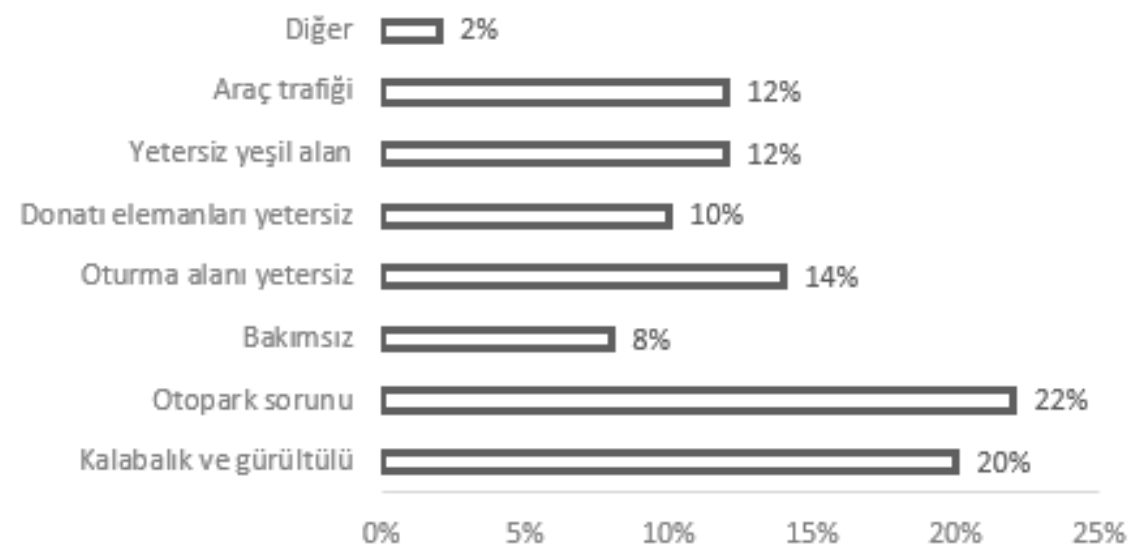

Şekil 11. Yayaların yaya bölgesinde beğenmedikleri unsurlar

Anket sonuçlarına göre, kullanıcı cinsiyeti ile alanda beğenilmeyen unsurlar arasında ilişki olup olmadığı incelenmiştir. Buna göre kadın katılımcılardan (\%28.7'si alanı kalabalık ve gürültülü bulurken \%15'i alandaki otopark sıkıntısından rahatsız olduklarını belirtmişlerdir. Bunun yanında erkek katılımcılardan $\% 27$ 'si alandaki otopark sorunundan şikayet ederken $\% 5$ 'i alanı bakımsız bulmuştur. Test sonuçlarına bakıldığında cinsiyetle alanda beğenilmeyen unsurların arasında anlamlı farklılık tespit edilmiştir (Çizelge 2).

Katılımcıların yaya bölgesinde görmek istedikleri kullanımların oranları Şekil 12' de verilmiştir. Buna göre katılımcıların \%24'ü su öğesi, \%17'si oturma birimleri, \%13'ü spor/oyun alanları, \%13'ü yeşil alanları, \%10'u gösteri alanı, \%9'u açık sergi alanı, \%7'si tuvalet, \%4'ü bilgi/reklam panoları ve saatler gibi kullanımları görmek istemektedirler.

Çizelge 2. Cinsiyet*alanda beğenmediğiniz unsurlar karşılaştırması

\begin{tabular}{llll}
\hline Chi-Square Tests & Value & df & Asymptotic Significance (2-sided) \\
\hline Pearson Chi-Square & $19.665^{\mathrm{a}}$ & 7 & .006 \\
Likelihood Ratio & 20.010 & 7 & .006 \\
Linear-by-Linear Association & 1.111 & 1 & .292 \\
N of Valid Cases & 250 & &
\end{tabular}

a. 2 cells (12.5\%) have expected count less than 5 . The minimum expected count is 2.30 . 


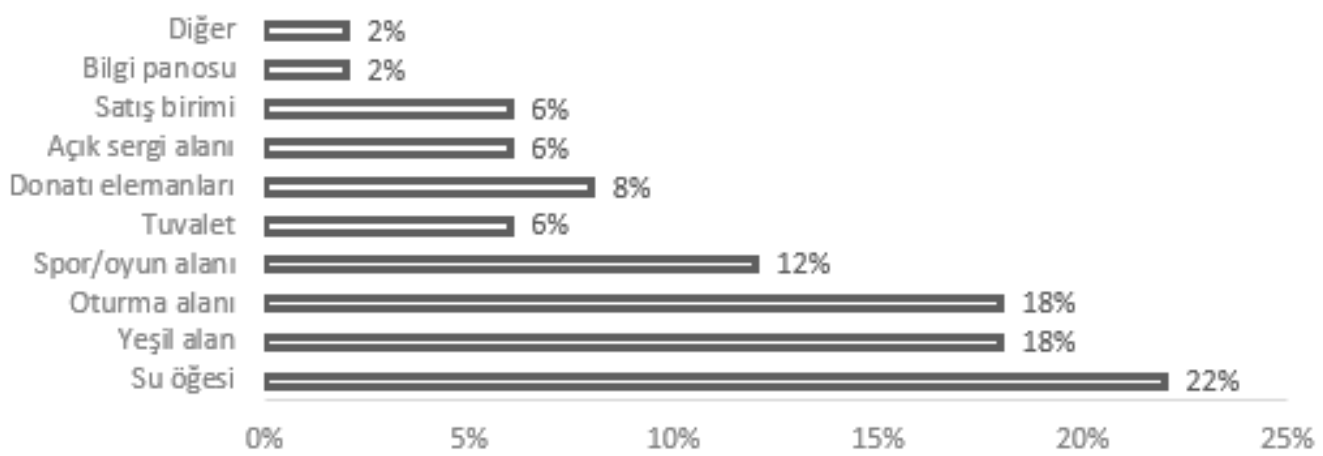

Şekil 12. Yayaların yaya bölgesinde olmasını istedikleri kullanımlar

Yayalara, yaya bölgesinin genel imajı ile ilgili düşünceleri sorulduğunda \%32'si alanı canlı ve dinamik \%18'i alanın bağlantı etkisini kuvvetli bulmaktadır. \%4'lük kısım kullanışı ve estetik öğeleri barındırmadığı görüşündeyken, \%26'sı yürüyüş yolunda yapılacak aktivite sayısının fazla olduğunu savunmaktadır (Şekil 13).

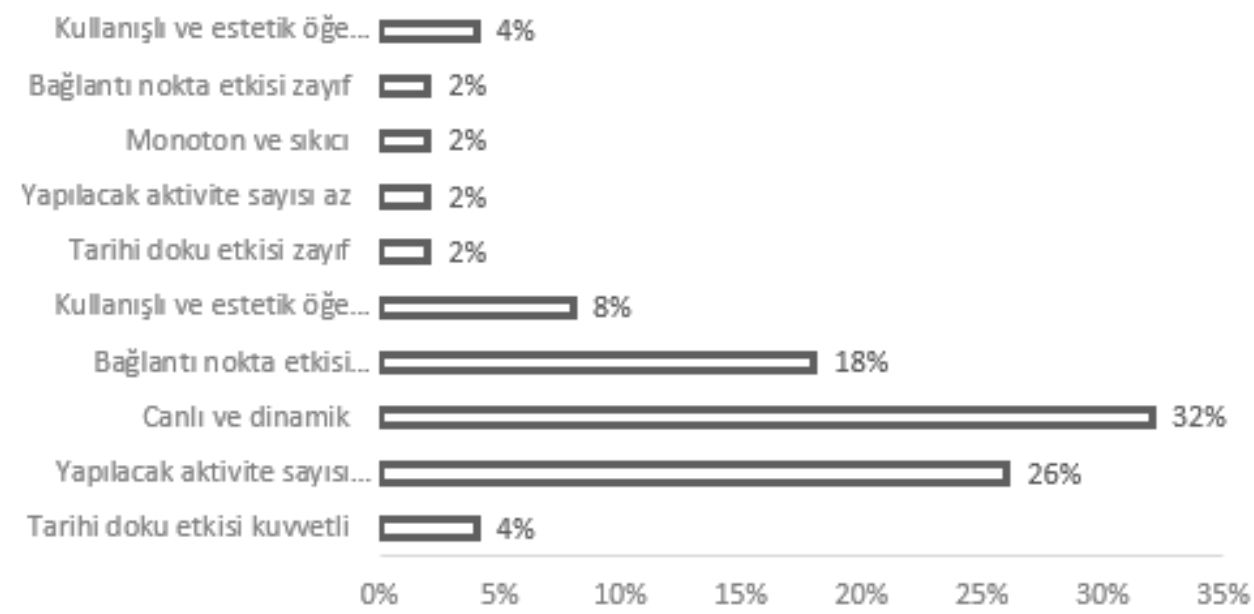

Şekil 13. Yayaların alanın genel imajı hakkındaki görüşleri

\subsubsection{Yaya bölgesindeki işyeri sahipleriyle yapılan anketlerin değerlendirilmesi}

Yaya bölgesindeki işyeri sahipleri ile yapılan ankete katılanların cinsiyet oranı oranlarına bakıldığında erkeklerin \%80'lik oranla çoğunlukta olduğu \%20'sini ise kadınların oluşturduğu görülmüştür.

İşyeri sahiplerinin yaş dağılımı incelendiğinde \%23'ünü 36-45 yaş arası bireyler oluştururken, \%28'ini $25-35$ yaş, $\% 12$ 'isini $18-24$ yaş ve $\% 29$ 'unu $46-54$ yaş grup bireyler oluşturmaktadır.

Yapılan ankete göre işyerlerinin \%35'i yeme-içme, \%23'ü tekstil, \%10'u elektronik eşya, \%9'u hediyelik eşya, \%9'u bakkal, \%4'ü kırtasiye, \%4'ü kuyumcu ve \%3'ü ise eczane niteliğindedir.

Anket çalışmasına katılan esnafların \%53'ü alana gelirken özel otomobilini kullandığını belirtmiştir. $\% 11^{\prime} i$ toplu taşıma araçlarıyla alana ulaşımını sağlarken, $\% 26$ 'sı yaya ve $\% 5$ 'i de bisiklet/motosiklet kullanarak alana erişimini sağlamaktadır (Şekil 14). 


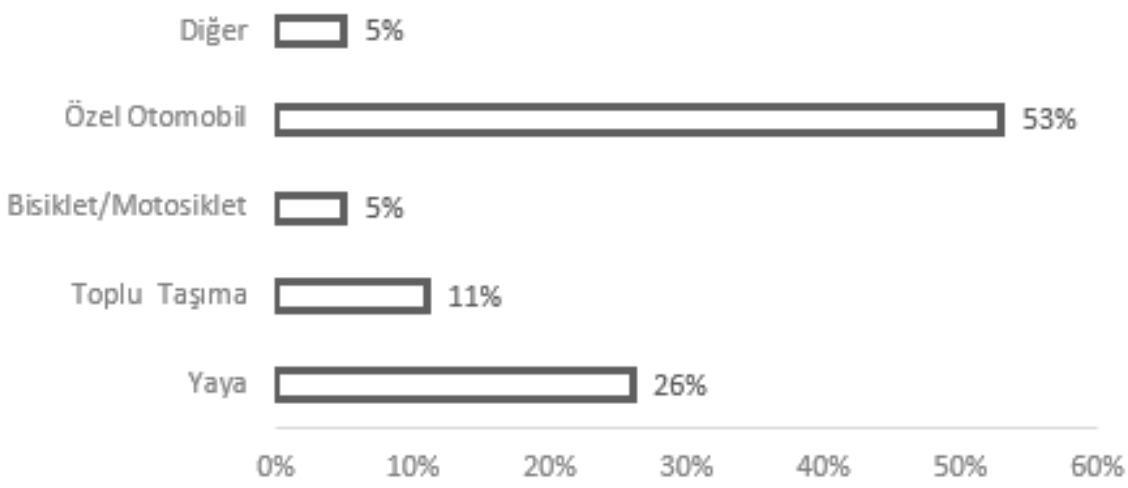

Şekil 14. İşyeri sahiplerinin alana ulaşım şekli

Yapılan anket çalışmasında alana özel araçlarıyla gelenlere otomobillerini nereye park ettikleri sorusu yöneltilmiş ve katılımcıların $\% 45^{\prime}$ inin otoparka, $\% 49$ 'unun kaldırım ve sokak aralarına, $\% 6$ 'sınında diğer alanlara park ettiği belirlenmiştir (Şekil 15).

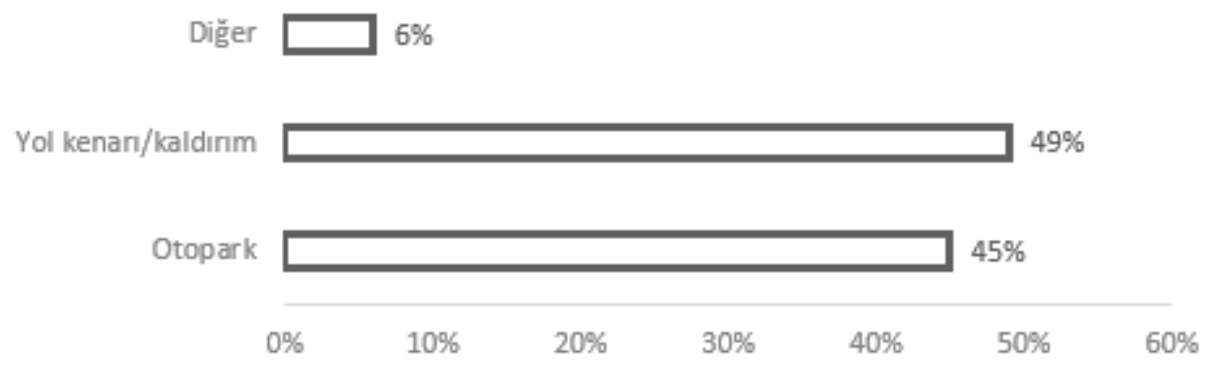

Şekil 15. İşyeri sahiplerinin araç park yeri tercihleri

İşyeri sahiplerinin malları nasıl taşıdıkları sorusuna \%31'i yaya olarak, \%35'i otomobil ile, \%17'si kamyonet ile, \%12'si hamal kullanarak, \%5'i ise diğer yöntemlerle mallarını dükkanlarına taşıdıklarını belirtmişlerdir.

İsyeri sahiplerin yayalaştırılmış bölgenin işyeri için olumlu etkisi olduğu görüşünü bildiren \% 67 'lik kısmı yürüyüş yolunun insanları alana çekerek satışlarının artmasını sağladığını, yürüyüş yolu ile alanda genel olarak temizlik ve güvenliğin arttığını, yaya bölgesinin alanı canlandırdığı ve esnafa kar getirdiğini savunurken birey olarak işverenlerinde yaya yürüyüş yolunu kullanım sıklığının arttığı görüşünü bildirmişlerdir. Bunun yanında \% $28^{\prime}$ lik kısım ise yaya yolunun müşteri sayısını azalttığını ileri sürmüş, ayrıca yürüyüş yolunun alanda gürültü kirliliğine neden olduğunu, otopark sorununun yaşanmasına yol açıı̆̆ını, daralan araç yolunda trafik oluşturduğunu ve esnafın dükkanlarına mal taşıma sırasında büyük sıkıntılar yaşadığını savunmuştur.

İşyeri sahipleriyle yapılan anketler sonucunda oluşturulan çapraz tablolarla Ki kare testleri yapılmış ve ikili ilişkilere bakıldığında eğitimin alanın genel imajıyla olumlu farklılık oluşturduğu tespit edilmiştir. Çizelge 3 ten de anlaşılacağı gibi lise mezunu işverenlerin (\%43.6), \%26.5'i alanı canlı ve dinamik bulurken, \%26.5'lik diğer kısım alanın tarihi dokusunun kuvvetli olduğunu savunmuştur bunun yanında \%5’lik oranla katılımcılar alanın bağlantı noktası etkisini yaratmadığını belirtmişlerdir.

Çizelge 3. Eğitim*alanın genel imajı karşılaştırması

\begin{tabular}{llll} 
Chi-Square Tests & Value & df & Asymptotic Significance (2-sided) \\
\hline Pearson Chi-Square & $42.991^{\mathrm{a}}$ & 24 & .010 \\
Likelihood Ratio & 28.305 & 24 & .247 \\
Linear-by-Linear Association & 7.189 & 1 & .007 \\
N of Valid Cases & 78 & & \\
\hline
\end{tabular}

a. 30 cells $(83.3 \%)$ have expected count less than 5 . The minimum expected count is .04 . 
Anket yapılan işyeri sahiplerinin \% 14'ü yürüyüş yolu içerisinde ve çevresinde bilgi/reklam panoları, \% 14'ü çöp kutusu, aydınlatma elemanı gibi donatı elemanları, \% 12'si yeşil alanlar, \% 16'sı su öğesi, \% 8'i spor alanları, \% 9'u tuvalet, \%8'lik kısmı sergi alanı ve \% $18^{\prime} i$ ise oturma alanları görmek istediğini belirtmiştir.

\section{Sonuç ve Öneriler}

Bu araştırma kapsamında incelen alanın yaya bölgeleri açısından değerlendirme sonuçları aşağıda özetlenmiş ve alanın geliştirmesine yönelik çeşitli önerilerde bulunulmuştur.

Yaya bölgelerinde çekiciliği arttırmak için kültürel miras önem taşımaktadır (Blaga 2013). Araştırma alanı tarihi bir geçmişe ve demiryoluna sahip olmasına karşın, yaya bölgesinin çekiciliğini arttıracak tarihi ve kültürel mirası yansıtacak unsurlar korunamamıştır. Alanda sadece hemzemin geçit işaretlerinin kullanılmış olması yeterli değildir. Alanın tarihi dokusunu yansıtacak, geçmişe atıf yapacak demiryolu ile ilişkili kullanımlara yer verilmesi alana kimlik kazandıracaktır. Alanın girişinde alanın tarihini anlatıldığı bilgi iletişim panosuna yer verilebilir. Dünyada en çok bilinen endüstriyel dönüşüm alanlardan olan, önceden demiryolu olarak kullanılan High Line Park (Manhattan New York); 1930'larda yük trenleri için inşa edilmiş, 1960-70 yılları arasında tren kullanımının azalmasıyla kısmi yıkımlara uğramış, 1980 'de ise kullanım dışı kalmıştır. Bu endüstriyel kalıntı terk edilmesi ile yabani bitkiler tarafından çevrilmiş çirkin bir yapıya dönüşünce, 1993 yılında Paris'te tamamlanan benzer bir proje olan Promenade Plantée ilham alınarak yeniden düzenleme ve yeşillendirme çalışmaları yapılımıştır. Demir yolunun yeniden kullanılması amacıyla 2006 yılında kentsel bir park inşa edilmeye başlandı, ilk kısmı 2009 yılında, ikinci kısmı 2011 yılında açılmıştır (Lopate, 2011). Çalışma alanında da High Line Parkta olduğu gibi tren rayları alanın belli noktalarında kullanılarak geçmişe atıf yapılabilir. Ayrıca kullanılan donatı elemanlarında da demiryolunun çizgisel özellikleri ile uyumlu tasarımlar yapılabilir.

Alan günümüzde bir ticaret merkezi olup yoğun trafiğe sahiptir. Bu yoğunluk yaya ve işyeri sahiplerinin özel araç kullanımını tercih etmeleri ve yaya bölgesinin iki yanında tek yönlü araç yolu bulunmasından kaynaklanmaktadır. Araç trafiği yaya bölgesi ile ticari mekanlar arasında bir engel oluşturmakta ve yaya güvenliğini azaltmaktadır. İyi bir yaya bölgesi taşıt trafiği olmadan yayalara güvenli bir ortam sunmalıdır. (Neill, 2002; Şişman, 2013; Asadi-Shekari, Moeinaddini ve Shah, 2015; Yıldırım ve Küçük, 2020). Ayrıca özel araç kullanım tercihi alanda otopark sorununu ortaya çıkarmış ve yapılan anketlerde bu sonucu desteklemiştir (\%22).

Yaya bölgeleri planlanırken ele alınması gereken en önemli unsurlardan biri doğru bir ulaşım planlaması yapmaktır. Kent merkezlerinde otopark zaten sorundur. Yaya bölgesi planlaması, belli sayıda park yerini ortadan kaldırarak, bu sorunu daha da arttırır. Bu durumlarda kaybedilen park alanları yaya alanı içerisinde veya uygun yürüme uzaklığı içinde sağlanmalıdır. Çoğu zaman sokak üzeri veya kaldırım üzeri parklar yeterli olmamakla birlikte uygun da değildir. Bu durumlarda çok katlı otoparklar dikkate alınmalıdır. Eğer yaya alanına paralel sokaklarda otopark yerleri oluşturulursa, bu yürüme uzaklığını azaltır. Otopark tesisleri, doğrudan yaya alanına bağlanan, yaya alt ve üst geçitleri ile bağlantılı oluşturulmalıdır (Çağlar, 1992). Dičiūnaitè-Rauktienè ve diğ. (2018)' de yaptıkları çalışmada özellikle engelli sürücüler ve çocuklu aileler ile yaşlılar için yaya alanlarına erişilebilir mesafelerde otopark alanlarının olması gerektiğini vurgulamışlardır. Blaga (2013) iyi bir yaya bölgesinin taşıt trafiği gürültüsünden arındırılmış olması gerektiğini belirtmektedir. Ancak, alanda kullanıcıların otopark sorunundan sonra, ikinci sırada kalabalık ve gürültüden (\%20) memnun olmadıkları belirlenmiştir. Yaya bölgeleri; rekreasyonel aktivitelere uygun, yürüme, seyretme ve oturma fonksiyonlarına cevap verebilecek özellikte ve sürdürülebilir kentsel bir çevre için yeşil alan bakımından yeterli olmalıdır (Gehl 2010; Blaga 2013; Balaban ve Puppim de Oliveira, 2014). Yapılan ankete sonuçları yaya bölgesinde oturma alanları (\%14) ve yeşil alanların (\%12) yetersiz olduğunu göstermiştir. Yaya bölgesinde yapılacak bitkisel düzenlemeler alanın estetik görünümünü arttıracağı gibi çevrenin kalitesini de olumlu etkileyecektir. Alanda korunması gereken elemanlardan birisi de tarihi çınar ağaçlarıdır. Bu ağaçların dışında bölge koşullarına uygun, fazla su istemeyen bitkiler seçilmeli, peyzaj planlama ve tasarım ilkeleri göz önünde bulundurularak düzenlemeler yapılmalıdır.

Sonuç olarak kentsel alanlarda yayalar için ayrılmış yaya bölgelerinin bulunması kentsel kalite açısından önem taşımaktadır. Başarılı bir yaya bölgesi tasarımı kent merkezleri için ekonomik, sosyal ve çevresel 
açıdan faydalar sağlamaktadır. Çalışma alanı da İzmit kent merkezinde yayalar için ayrılmış alanlardan biridir. Bu çalışma göstermiştir ki alana yapılacak bazı düzenlemeler alanı daha cazip ve kullanılabilir bir duruma getirilebilir.

\section{Teşekkür ve Bilgi Notu}

Bu makale, Tekirdağ Namık Kemal Üniversitesi Fen Bilimleri Enstitüsü Peyzaj Mimarlı̆̆ Ana Bilim Dalı'nda 2017 yılında tamamlanan Yüksek Lisans tezinden üretilmiştir. Makalede, ulusal ve uluslararası araştırma ve yayın etiğine uyulmuştur. Çalışmada etik kurul izni gerekmemiştir.

\section{Kaynaklar}

Aru, K. A. (1965). Yayalar, Taşıtlar, Şehir Dokusunda Yeni Ulaştırma Düzenleri, iTÜ Mimarlık Fakültesi Yayınları, İstanbul, s.219.

Asadi-Shekari, Z., Moeinaddini, M., Shah, M. Z. (2015). Pedestrian safety index for evaluating street facilities in urban areas. Saf. Sci. , 74, 1-14.

Balaban, O., Puppim de Oliveira, J. A. (2014). Understanding the links between urban regeneration and climate-friendly urban development: lessons from two case studies in Japan. Local Environment, Vol. 19, No. 8, P:868-890.

Blaga, O. E. (2013). Pedestrian ones as important urban strategies in redeveloping the communityCase study: Alba lulia Borough park. Transy/vanian Rev. Admin. Sci., 38, 5-22

Carr, S., Francis, M., Rivlin, L. G. and Stone, A. M. (1992). Public Space. Cambridge University Press. 400p.

Çalışkan, M. (2011). Kamu Yararı Bağlamında Kamusal Mekanlarda Bir Yayalaştırma Örneği: Eminönü Tarihi Yarımada (Hobyar Mahallesi ve Çevresi) Yayalaştırma Projesi. (Yayınlanmamış Yüksek Lisans Tezi), Fen Bilimleri Enstitüsü, İstanbul.

Çağlar, T. N. (1992). Konut Alanları ve Alış- Veriş Merkezlerindeki Kent Sokaklarının Çağdaş Tasarımları Üzerinde Bir Araştırma. (Yayınlanmamış Doktora Tezi) A.Ü. Fen Bilimleri Enstitüsü, Ankara.

Çermikli, B. (2009). Yaya Bölgelerinde Kullanım Analizi Üzerine Bir Araştırma: Beyazıt Meydanı ve Çevresi Örneği. (Yayınlanmamış Yüksek Lisans Tezi), İstanbul.

Dičiūnaitè-Rauktienė, R., Gurskienè, V., Burinskienè, M. ve Maliene, V., (2018). The Usage and Perception of Pedestrian Zones in Lithuanian Cities: Multiple Criteria and Comparative Analysis. Sustainability: 10, 818.

Gehl, J. (2010). Cities for People. Island Press: Washington, DC, USA, pp. 266-278.

Keleş, R. (1980). Kent bilim terimleri sözlüğü. Türk Dil Kurumu Yayınları, Senis Basımevi, Ankara, 188s.

Kuntay, O. (1994). Yaya Mekanı. Ayıntap Yayıncılık, s:91, Ankara.

Lopate P. (2011). Above Grade: On the High Line, Places Journal, November 2011. Erişim Tarihi: 22 May 2021. https://placesjournal.org/article/above-grade-on-the-high-line/

Melia, S., Barton, H. ve Parkhurst, G. (2010). Carfree, Low Car - What's the Difference? World Transport Policy \& Practice 16 (2), 24-32.

Mulliner, E. ve Maliene, V. (2011). An introductory review to the Special Issue: Attractive places to live. Urban Des. Int. 16, 147-152.

Neill M. J. (2002). City of abbotsford: establishing greenvvays criteria. Master of Urban and Rural Planning, Dalhousie University, Halifax, Nova Scotia, 21.

Ornetzeder, M., Hertwich, E. G., Hubacek, K., Korytarova, K. ve Haas, W. (2008). The environmental effect of car-free housing: A case in Vienna. Ecological Economics 65 (3), 516-530.

Rosen, S. B. (2006). The success and failure of pedestrian malls in Europe and America. Senior Project, City and Regional Planning Department California Polytechnic State University San Luis Obispo. 
Rubenstein, H. M. (1992). Pedestrian Malls, Streetscapes and Urban Spaces. John Wiley\&Sons, Inc.

Sen, S. (1999). Toward A Typology of Transportation-Related Urban Design Problems and Solutions: Case Studies of Small And Medium Sized Cities in The Eastern United States. National Transportation Center Morgan State.

Şişman E. ve Kırzıoğlu I. (2002). Erzurum Kent Merkezinde Yaya Bölgesi Olabilecek Kent Mekan Birimlerinin Saptanması ve Projelendirilmesi Üzerine Bir Araştırma. Trakya Üniversitesi Bilimsel Araştırma Dergisi Cilt.3, Edirne.

Şişman E. E. ve Etli, B. (2007). Tekirdağ Kent Merkezindeki Yaya Bölgelerinin Belirlenmesi ve Projelendirilmesi, Tekirdağ Ziraat Fakültesi Dergisi.4(3): 327-338

Şişman E. E. (2013). Pedestrian Zones. Advances in Landscape Architecture Section 3 Urban Landscape Chapter 16 P: 401-426.

Şenkaynak., P., (2010). Yaya Bölgelerinin Kentsel Peyzaj Planlama Açısından Önemi ve İstanbul'daki Bazı Örneklerin İncelenmesi, (Yayınlanmamış Yüksek Lisans Tezi), İstanbul.

Yıldırım, A, Küçük, V. (2020). Yayalaştırılmış Bölge Kafeler Caddesi'nin (Isparta) Peyzaj Mimarlığı Açısından İrdelenmesi. Mimarlık Bilimleri ve Uygulamaları Dergisi (MBUD), 5 (1), 81-92. DOI: 10.30785/mbud.669463 